\title{
Prepartum feeding level and body condition score affect immunological performance in grazing dairy cows during the transition period
}

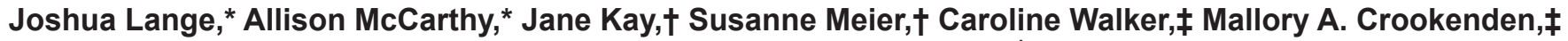 \\ Murray D. Mitchell,§ Juan J. Loor,\# John R. Roche, † and Axel Heiser*1 \\ ${ }^{*}$ AgResearch, Hopkirk Research Institute, Grasslands Research Centre, Palmerston North, New Zealand 4442 \\ †DairyNZ Limited, Private Bag 3221, Hamilton, New Zealand 3240 \\ †DairyNZ Limited, School of Biological Sciences, University of Auckland, New Zealand 1010 \\ $\S U n i v e r s i t y$ of Queensland, Centre for Clinical Research, Royal Brisbane and Women's Hospital Campus, Herston, Queensland 4029, Australia \\ \#Department of Animal Sciences, University of Illinois, Urbana 61801
}

\begin{abstract}
Precalving feeding level affects dry matter intake, postcalving energy balance, the risk of hepatic lipidosis and metabolic disease, and gene expression in liver and adipose tissue. These coincide with a higher risk of disease postpartum and, very likely, a failure to reach optimum production as well as reproductive targets. Current interpretation of the available evidence suggest that metabolic stressors affect the immune system of transition dairy cows and lead to reduced immunocompetence. The objective of the current study was to investigate the effect of precalving body condition score (BCS) and level of feeding on immunocompetence during the peripartum period. Twenty-three weeks before calving, 78 cows were allocated randomly to 1 of 6 treatment groups $(\mathrm{n}=13)$ in a $2 \times 3$ factorial arrangement: 2 precalving BCS categories (4.0 and 5.0, based on a 10-point scale) and 3 levels of energy intake during the 3 wk preceding calving $(75,100$, and $125 \%$ of estimated requirements). Blood was sampled precalving and at 1,2 and 4 wk after calving. Cells were analyzed by flow cytometry and quantitative real-time PCR. The numbers of T helper lymphocytes (CD4+), cytotoxic T lymphocytes (CD8+), natural killer cells (CD335+), and $\gamma \delta \mathrm{T}$ lymphocytes (WC1+) as well as their activation status [IL-2 receptor (CD25) + cells] were highly variable between animals, but there was no evident effect of BCS, feeding level, or time. All groups presented with an increase in expression of cytokines in unstimulated blood cells in the week after calving, although this was significant only for IFNG in the BCS 4.0 group. Analysis of in vitro-stimulated cells allowed 2 general observations: (1) cows with high energy intake precalving (125\%) had increased cytokine expres-
\end{abstract}

Received July 19, 2015.

Accepted November 22, 2015.

${ }^{1}$ Corresponding author: axel.heiser@agresearch.co.nz sion precalving, and (2) all cows had increased cytokine expression in the week after calving. The present study provides evidence that prepartum feed management can affect immunocompetence during the transition period. Considering the current results, optimally conditioned animals might benefit from a restricted precalving diet, whereas underconditioned cows can be fed to requirements.

Key words: immunity, immunocompetence, peripartum period, transition cow

\section{INTRODUCTION}

For dairy cows, transitioning from late pregnancy to early lactation poses a significant metabolic challenge (Bell, 1995; Drackley et al., 2005). These metabolic adaptations are likely the reason for immunologic changes (Goff and Horst, 1997; Ingvartsen and Moyes, 2013; Heiser et al., 2015) that contribute to an estimated 30 to $50 \%$ of dairy cows experiencing metabolic or infectious disease in the period immediately postcalving (LeBlanc, 2010). Neutrophils and their role in innate immune defense against mastitis have been a focus of previous research (Gilbert et al., 1993; Madsen et al., 2002; Hammon et al., 2006; Graugnard et al., 2012), whereas others have analyzed lymphocyte function, primarily measuring mitogen-induced lymphocyte proliferation (Kehrli et al., 1989; Lessard et al., 2004; Lacetera et al., 2005; Karcher et al., 2008; Schwarm et al., 2013; Heiser et al., 2015; Nightingale et al., 2015). From these studies, it can be concluded that immune function is modulated during the peripartum period, which likely affects susceptibility to infectious diseases after calving. However, there is a need for further analysis of the mechanisms involved and predictive biomarkers to allow identification of susceptible animals in time for preventive intervention.

To provide a broader analysis of immune function in transition cows in this study, we used flow cytometry 
and a combination of in vitro stimulation and fluorescence-based quantitative real-time PCR (qPCR) to analyze the cellular composition of peripheral blood mononuclear cell (PBMC) subsets from pasture-based dairy cows as well as the immunological performance of these cells. Immunological performance was investigated by analyzing expression of mRNA encoding for selected cytokines after in vitro stimulation. Interferon- $\gamma($ IFNG) is critical for innate and adaptive immune responses against viral and intracellular bacterial infections and is also a key activator of macrophages (Schroder et al., 2004). Tumor necrosis factor (TNF) regulates immune cells, with variable effects. Dysregulation of IFNG and $T N F$ is associated with several diseases (Locksley et al., 2001). Interleukin-17 (IL17) acts similarly to IFNG and synergistically with $T N F$. It is produced by $\mathrm{T}$ lymphocytes and supports migration of monocytes and neutrophils to the site of inflammation (Jin and Dong, 2013). In contrast to these proinflammatory cytokines, IL-10 (IL10) is considered an antiinflammatory cytokine (Couper et al., 2008).

Despite a significant number of studies investigating the metabolic and molecular changes associated with dietary energy intake before calving (Schmitt et al., 2011; Graugnard et al., 2012; Ji et al., 2014; Akbar et al., 2015), the underlying mechanisms are still unclear. Roche et al. (2013) reported significant effects of calving BCS on cow metabolic profiles, supporting the hypothesis that the effect of precalving level of feeding is dependent on precalving BCS (Roche et al., 2015). The objective of the current study was to investigate the effect of precalving BCS and level of feeding on immunocompetence during the peripartum period with the long-term goal of developing feeding recommendations for improved immune function.

\section{MATERIALS AND METHODS}

Animals were sourced from an experiment undertaken at Scott Farm (Hamilton, New Zealand; $37^{\circ} 46^{\prime} \mathrm{S}$ $175^{\circ} 18^{\prime} \mathrm{E}$ ) between January and October 2013 that was reported by Roche et al. (2015). After passing a clinical examination, 150 cows were enrolled in the experiment on January 21, 2013. Cows were allocated randomly to 1 of 6 treatment groups (13 cows per group) in a 2 $\times 3$ factorial arrangement: 2 precalving BCS categories (4.0 and 5.0; based on a 10-point scale, where 1 is emaciated and 10 obese, $\mathbf{B} \mathbf{4}$ and $\mathbf{B 5}$, respectively; Roche et al., 2004) and 3 levels of energy intake during the 3 wk preceding calving $(75,100$, and $125 \%$ of estimated requirements, F75, F100, and F125, respectively; Roche et al., 2005). Although cow allocation to treatment was random, groups were assessed to ensure they represented typical New Zealand dairy cows from a management and genetic perspective and were balanced for age, breed, BCS at the time of enrollment, and expected calving date. Age at enrollment was $4.0 \pm$ $1.4 \mathrm{yr}$ (mean $\pm \mathrm{SD}$ ). To generate the $2 \mathrm{BCS}$ treatment groups before the end of lactation, feeding levels were manipulated starting on February 1 (205 DIM). Therefore, 3 groups of cows were assigned to gain, maintain, or lose BCS. All animals grazed an allowance of fresh pasture and were supplemented with pasture silage, corn silage, and palm kernel expeller. From $23 \pm 5.6 \mathrm{~d}$ precalving, cows were offered fresh pasture at 75, 100, or $125 \%$ of their estimated ME requirements (Roche et al., 2005). Further details of the approach to establish treatment groups are described elsewhere (Roche et al., 2015). The mean calving date was July $11 \pm 10.2$ d. All animal manipulations were in accordance with the New Zealand Animal Welfare Act (1999) and had approval of the Ruakura Animal Ethics Committee (Hamilton, New Zealand).

\section{Blood Samples}

Blood was sampled on multiple days via coccygeal venipuncture at approximately $0800 \mathrm{~h}$. To allow analysis of immunocompetence for a period starting before calving and covering an extended time after calving (4 wk) while maintaining feasibility and considering animal welfare, samples were taken at 4 time points. One sample each per time point (and 13 animals per treatment group) was taken at 1 to $17 \mathrm{~d}$ before calving (Pre), 3 to $11 \mathrm{~d}$ (wk +1$), 12$ to $18 \mathrm{~d}(\mathrm{wk}+2)$, and 25 to $35 \mathrm{~d}(\mathrm{wk}+4)$ after calving. Blood was collected into evacuated blood tubes containing lithium heparin as an anticoagulant (Vacutainer, Becton, Dickinson and Co., Franklin Lakes, NJ). Following a procedure that showed good results in a previous study (Heiser et al., 2015), samples were shipped over night at ambient temperature to the Hopkirk Research Institute (Palmerston North, New Zealand) for further processing.

\section{Phenotypic Analysis by Flow Cytometry}

Peripheral blood leukocyte populations were analyzed using flow cytometry. The following antibodies were used: natural killer (NK) cells were identified using bovine CD335 (A488 conjugated, clone AKS1; Storset et al., 2004); $\gamma \delta$-T lymphocytes were identified using antiWC1 [fluorescein isothiocyanate (FITC)-conjugated, clone CC15; Clevers et al., 1990]; T helper cells were identified using bovine CD4 (AlexaFluor 647-conjugated, clone CC8; Bensaid and Hadam, 1991); cytotoxic T lymphocytes (CTL) were identified using bovine CD8 (FITC-conjugated, clone CC63; MacHugh and Sopp, 1991); cells expressing the IL-2 receptor (CD25) were 
identified using bovine CD25 (phycoerythrin-conjugated, clone ILA111; Naessens et al., 1992). All antibodies were from Abd Serotec/Bio-Rad (Hercules, CA).

For analysis, $5 \mu \mathrm{L}$ each of various antibodies were transferred into FACS (fluorescence-activated cell sorter) tubes, and $200 \mu \mathrm{L}$ of whole blood was added and incubated for $20 \mathrm{~min}$ at room temperature in the dark. Lysis of red blood cells was performed by adding $2 \mathrm{~mL}$ of distilled water for no more than $2 \mathrm{~min}$. Subsequently, $200 \mu \mathrm{L}$ of $10 \times$ PBS was added while vortexing the tubes. Samples were then centrifuged and washed twice with PBS, both at $300 \times g$ for $7 \mathrm{~min}$ at room temperature. Finally, cell pellets were resuspended in $200 \mu \mathrm{L}$ of PBS and analyzed using a FACSCalibur cell sorter (Becton Dickinson, Franklin Lakes, NJ). A gate for leukocytes was drawn containing lymphocytes and monocytes based on their forward and sideward scatter characteristics. For each cell type, the percentage of cells within this gate expressing the surface marker was determined. Activated cells were defined as the percentage CD25-positive cells for each of the cell types.

\section{In Vitro Stimulation of Blood Samples}

For in vitro stimulation, $2 \mathrm{~mL}$ of whole blood was transferred to a $50-\mathrm{mL}$ tube. Stimulation was performed by adding $20 \mu \mathrm{L}$ of Staphylococcal enterotoxin B (SEB) and LPS (both from Sigma-Aldrich, St. Louis, $\mathrm{MO})$ to a final concentration of $500 \mathrm{ng} / \mathrm{mL}$ each. For each blood sample, another $2 \mathrm{~mL}$ of whole blood was used without stimulation. Tubes were incubated for 22 $\mathrm{h}$ at $37^{\circ} \mathrm{C}$ in $5 \% \mathrm{CO}_{2}$. Warmed $\left(37^{\circ} \mathrm{C}\right)$ Tris-buffered ammonium chloride lysis buffer was added to lyse red blood cells and samples were incubated for $10 \mathrm{~min}$ at $37^{\circ} \mathrm{C}$. After centrifugation, 2 washes with PBS $(300 \times$ g, $7 \mathrm{~min}$, room temperature) were performed, cell pellets were resuspended in TRIzol (Invitrogen, Carlsbad, $\mathrm{CA}$ ) and frozen at $-80^{\circ} \mathrm{C}$.

The Bovigam ELISA test kit for bovine IFNG (Prionics, Schlieren, Switzerland) was used to determine the amount of IFNG released into cell supernatants. The amount of IFNG was calculated against a standard curve prepared with recombinant IFNG.

\section{RNA Preparation}

Samples were retrieved from $-80^{\circ} \mathrm{C}$ storage and quickly thawed for subsequent preparation of RNA. The phases were separated by adding $200 \mu \mathrm{L}$ of chloroform and vigorously shaking by hand for $15 \mathrm{~s}$, followed by incubation for 2 to $3 \mathrm{~min}$ at room temperature. Samples were centrifuged at $12,000 \times g$ for $15 \mathrm{~min}$ at $4^{\circ} \mathrm{C}$. The top aqueous layer was transferred to a fresh microcentrifuge tube, and $5 \mu \mathrm{g}$ of RNase-free glycogen
(Invitrogen) added. After precipitation of RNA in the aqueous phase by addition of $500 \mu \mathrm{L}$ of $100 \%$ isopropanol and incubation at room temperature for $20 \mathrm{~min}$, samples were centrifuged at $12,000 \times g$ for 15 min at $4^{\circ} \mathrm{C}$. Isopropanol was removed by decanting and briefly draining liquid from the inverted tube. The pellet was washed by adding $1 \mathrm{~mL}$ of $75 \%$ ethanol [ethanol in diethylpyrocarbonate (DEPC)-treated water] and centrifugation at $8,000 \times g$ for $5 \mathrm{~min}$ at $4^{\circ} \mathrm{C}$. The supernatant was removed and the RNA pellets air-dried for 5 min. Twenty microliters of DEPC-treated water was used to dissolve the RNA, and a Nanodrop 1000 spectrophotometer (Thermo Fisher Scientific, Waltham, MA) was used to determine RNA concentration and ratio of absorbance at 260 and $280 \mathrm{~nm}$ (A260/A280). The RNA samples were adjusted to 0.2 to $1.0 \mu \mathrm{g} / \mu \mathrm{L}$ by adding DEPC-treated water and stored at $-80^{\circ} \mathrm{C}$.

\section{DNase Treatment and DNA Preparation}

Residual genomic DNA was removed by combining $1 \mu \mathrm{g}$ of RNA sample with $1 \mu \mathrm{L}$ of $10 \times$ DNase I buffer, $1 \mu \mathrm{L}$ of DNase I (both Invitrogen), and DEPC-treated water to a total volume of $10 \mu \mathrm{L}$. Samples were centrifuged at $10,000 \times g$ for $15 \mathrm{~min}$ at $4^{\circ} \mathrm{C}$ and incubated at room temperature for 15 min. Inactivation of DNase was achieved by adding $1 \mu \mathrm{L}$ of $25 \mathrm{~m} M$ EDTA, centrifuging at $10,000 \times g$ for $15 \mathrm{~min}$ at $4^{\circ} \mathrm{C}$, and incubating at $65^{\circ} \mathrm{C}$ for $10 \mathrm{~min}$.

For cDNA preparation, $10 \mu \mathrm{L}$ of DNase I-treated RNA was combined with $1 \mu \mathrm{L}$ of Oligo (dT) 20 primer (at $500 \mu \mathrm{g} / \mathrm{mL}=0.5 \mu \mathrm{g}$; Invitrogen) and $2 \mu \mathrm{L}$ of DEPC-treated water and incubated at $65^{\circ} \mathrm{C}$ for $10 \mathrm{~min}$. Samples were quickly cooled and centrifuged briefly. Seven microliters of reverse transcriptase Master Mix (Roche, Basel, Switzerland) was added to each reaction, mixed gently, and centrifuged briefly. Samples were incubated at $55^{\circ} \mathrm{C}$ for 30 min followed by prompt inactivation of the enzymes at $80^{\circ} \mathrm{C}$ for $5 \mathrm{~min}$. The DNA samples were stored at $-20^{\circ} \mathrm{C}$.

\section{Fluorescence-Based Quantitative Real-Time PCR}

For quantitative real-time (q)PCR analysis, $10 \mu \mathrm{L}$ of SyBr Premix Ex TaqII master mixture (Takara/ Clontech, Mountain View, CA), $1 \mu \mathrm{L}$ of template cDNA, $1 \mu \mathrm{L}$ of each gene-specific primer $(5 \mathrm{mM})$, and $7 \mu \mathrm{L}$ of sterile Milli-Q water (Millipore, Billerica, MA) were combined in a $20-\mu \mathrm{L}$ reaction mixture in duplicate. Primer sequences for U1,IFNG, TNF, IL17, and IL10 were published previously (Heiser et al., 2015). A Rotor-Gene 6000 real-time PCR system (Corbett Life Science, Mortlake, NSW, Australia) was used and the cycle number at which the various transcripts be- 
come detectable, referred to as threshold cycle $(\mathbf{C t})$, with threshold 0.05 . The first 5 cycles were eliminated using Rotor-Gene 6000 series software 7.0 (Corbett Life Science). The threshold for detection was set to $32 \mathrm{Ct}$; anything above that was defined as "not expressed." The mean Ct value of duplicate reactions was used for calculations. For analysis of unstimulated cells, expression levels were calculated as $\Delta \mathrm{CT}$; that is, $\mathrm{Ct}$ of gene of interest minus $\mathrm{Ct}$ of reference gene $(U 1)$. For analysis of in vitro-stimulated cells, $\Delta \Delta \mathrm{CT}$ was calculated according to $\Delta \mathrm{Ct}$ of stimulated blood minus $\Delta \mathrm{Ct}$ of unstimulated blood.

\section{Statistical Analysis of qPCR}

A repeated-measures model with a variance-covariance structure of autoregressive order 1 within each cow was used to analyze the data, considering BCS (B4 and B5), feeding management (F75, F100 and F125), and time (Pre, wk +1 , wk +2 and wk +4 ) as well as the interaction of BCS and feeding level as fixed effects. A transformation (natural log) was applied to match the normality assumption of the modeling. Normalized, log-2 transformed data were subjected to "nlme" and "predictmeans" in R 3.1.1 (R Core Team, 2015); $P$ values $<0.05$ were considered statistically significant.

\section{RESULTS AND DISCUSSION}

\section{Cellular Composition of Blood from Periparturient Cows}

Banos et al. (2013) reported several significant correlations between immune traits and other recorded traits, including incidence of lameness and percentage CD335positive NK cells, subclinical mastitis and CD4:CD8 ratio, as well as fertility and percentage of CD8-positive CTL. To detect changes in these cell populations during the peripartum period, whole-blood samples from study animals were analyzed for expression of cell typespecific markers using flow cytometric analysis. The numbers of $\mathrm{T}$ helper lymphocytes (CD4+), cytotoxic T lymphocytes (CD8+), NK cells (CD335+), and $\gamma \delta \mathrm{T}$ lymphocytes ( $\mathrm{WC} 1+)$, as well as their activation status [IL-2 receptor $(\mathrm{CD} 25)+]$, were highly variable between animals, which was expected because dairy cows are an outbred population. No effects of BCS, feeding level, or time (Figure 1) were evident. Across all time points and treatment groups, $3.9 \pm 1.9 \%$ of the cells were CD335+ NK cells, of which $4.8 \pm 2.8 \%$ were activated; WC1 $+\gamma \delta$-T cells comprised $8.1 \pm 2.4 \%$ of the cells and $6.9 \pm 3.2 \%$ of them were activated. In total, $12 \pm$ $3.9 \%$ of the cells were CD4+ T helper cells, of which 25 $\pm 14 \%$ were activated; CD $8+$ CTL contributed $8.2 \pm$
$3.6 \%$ of the cells and $19 \pm 10 \%$ of them were activated. The CD4:CD8 ratio was $2.1 \pm 1.7$, suggesting a normal distribution of these cell types.

The size of the cellular subpopulations was similar to that in previous reports (Boysen and Storset, 2009; Hoek et al., 2009; Maślanka et al., 2012; Banos et al., 2013). An increase in NK cell number from pre- to postcalving, as described in a previous study (Heiser et al., 2015), was not evident in this study. These results suggest that BCS and feeding level do not influence the size of lymphocyte subpopulations during the peripartum period. These cell types also do not generally change during this time. However, individual animals can experience changes in lymphocyte subpopulations that subsequently may influence susceptibility to infectious diseases. Investigation of such potential correlations between cell populations, cytokine responses, metabolic parameters, and animal health, productivity, and reproduction is subject to current and ongoing analysis.

\section{Cytokine Gene Expression and Secretion in Immunocompetence Assay}

Posttranscriptional mechanisms contribute to the control of protein expression in immune effector cells (Ivanov and Anderson, 2013). To ensure the relevance of measuring mRNA levels, expression of IFNG and IL17 in the immunocompetence assay was compared at the mRNA and protein levels (Figure 2). Across all data pairs, combining treatments and time points, the in vitro-stimulated samples secreted 1,200 $\pm 2,300 \mathrm{pg} /$ $\mathrm{mL}$ of IFNG and 1,400 $\pm 3,100 \mathrm{pg} / \mathrm{mL}$ of IL17, as measured by ELISA $(\mathrm{n}=245$; mean $\pm \mathrm{SD})$. These results correlated well (Figure 2) with the Ct values obtained from qPCR from the same samples, which were $5.6 \pm$ 2.3 for $\operatorname{IFNG}\left(\mathrm{R}^{2}=0.87\right)$ and $5.6 \pm 2.7$ for $\operatorname{IL17}\left(\mathrm{R}^{2}=\right.$ $0.87)$. These results confirm the relevance of $\mathrm{qPCR}$ for the measurement of cytokine release from bovine cells.

\section{Cytokine Expression in Bovine Blood Leukocytes from Periparturient Cows}

In immunocompetence studies, cytokine levels are usually measured from stimulated lymphocytes and results are normalized against unstimulated cells. Here, cytokine expression in unstimulated cells was analyzed to investigate potential effects of BCS, feeding level, and time on the baseline expression of cytokines. Expression of the cytokines IFNG, TNF, IL17, and IL10 was variable between individual animals, with an average coefficient of variation of $26 \%$ across all time points and treatments. Almost all groups presented with an increase in expression of all 4 cytokines in the week 


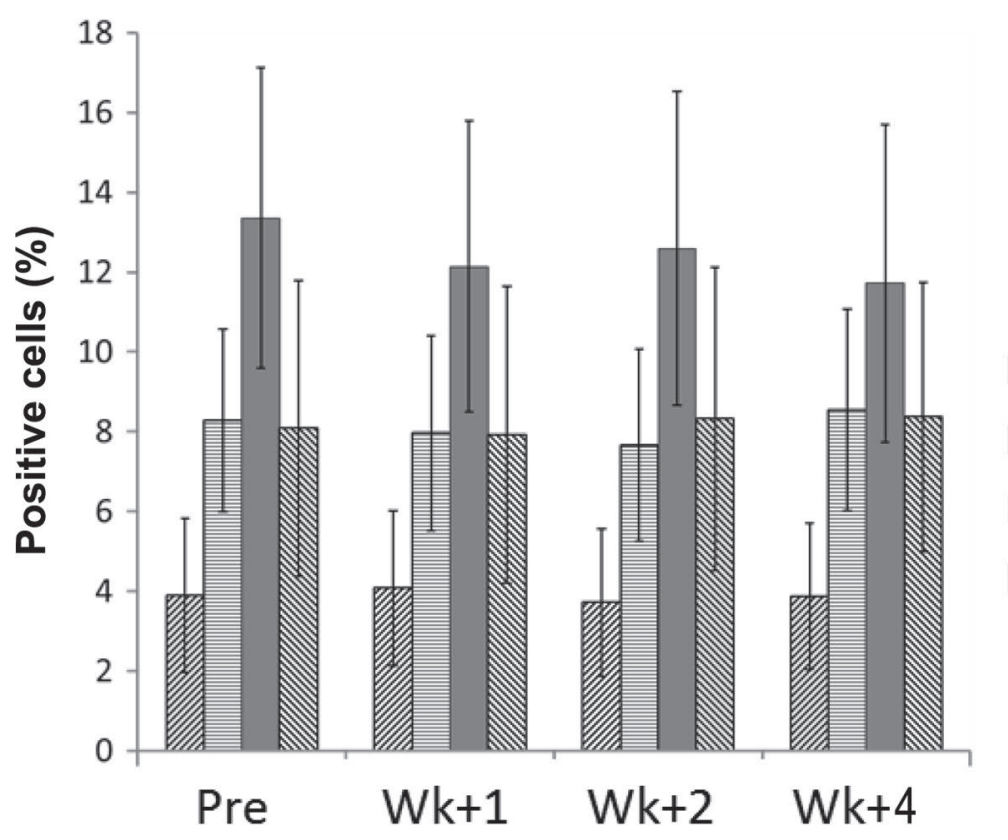

淈 NK cells (CD335+) 目 $\gamma \delta$ T cells $(\mathrm{WC} 1+)$

$\square$ Th cells $(C D 4+)$

$\mathbb{Q} \mathrm{CTL}(\mathrm{CD} 8++)$

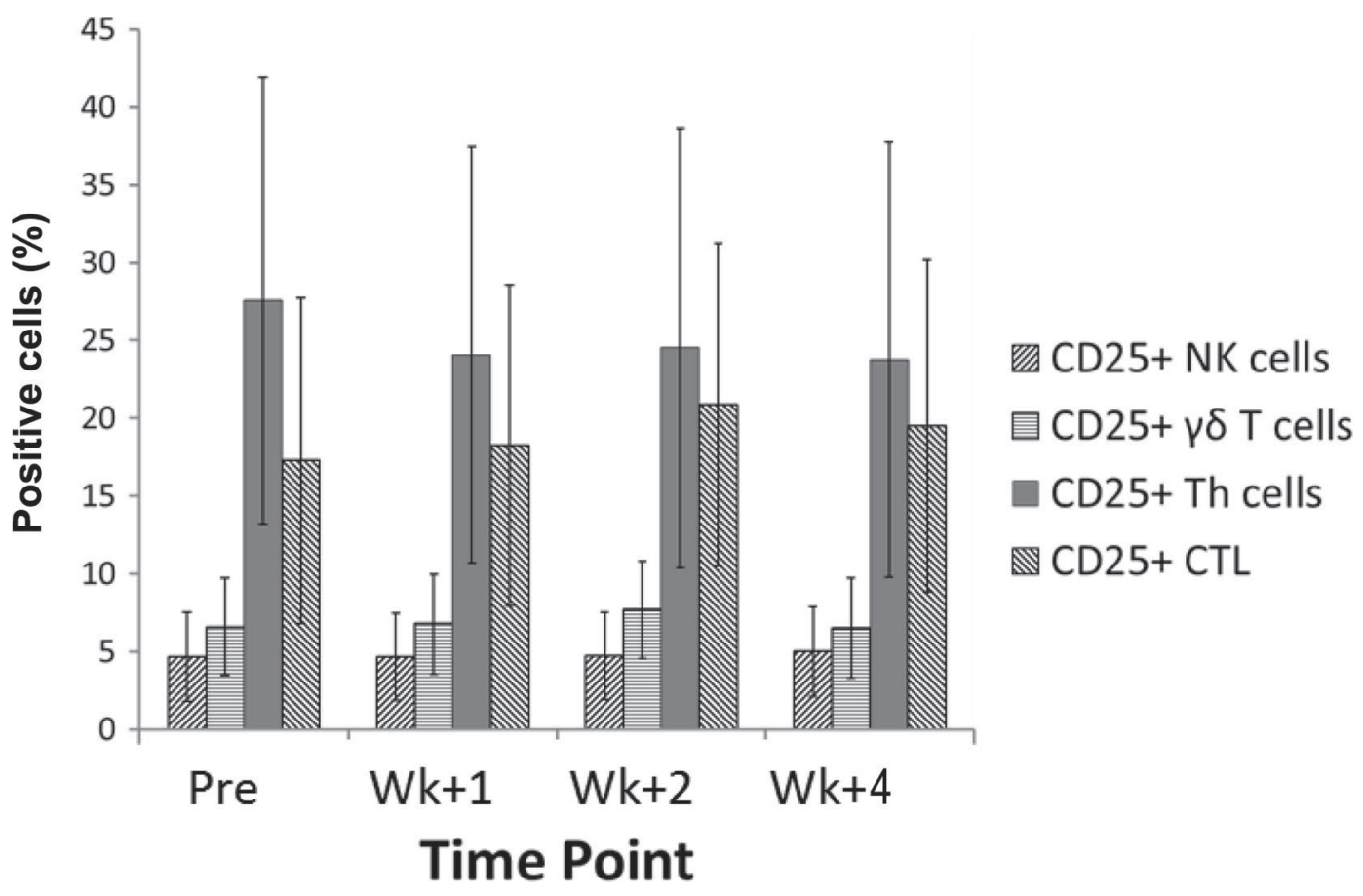

Figure 1. Cellular composition of bovine blood during the peripartum period. Blood was sampled from 60 dairy cows precalving (Pre) and $1,2$ and 4 wk after calving (wk $+1,+2,+4)$ and analyzed using flow cytometry for the relative number of cells expressing CD335 [natural killer (NK) cells], WC1 ( $\gamma \delta \mathrm{T}$ cells), CD4 [T helper (Th) cells], and CD8 (cytotoxic T cells, CTL); top]. CD25 (IL-2 receptor) was detected on subpopulations of these cell types (bottom) and can be interpreted as being an activation marker (mean \pm SD).

after calving (wk +1 ; Figure 3 ), although this was significant only for $I F N G$ in the BCS4 groups $(P<0.05)$. A clear exception was group B5F125, which had stable levels of $I F N G$ from Pre to wk +2 and a decrease at wk $+4(P<0.05)$. Expression of IL10 was lower $(P<0.05)$ in BCS5 groups compared with BCS4 groups; IL10 is an antiinflammatory cytokine (Couper et al., 2008) that prevents immune system-mediated damage to the host by limiting the immune response (Banchereau et al., 2012). An earlier study in transition cows that 

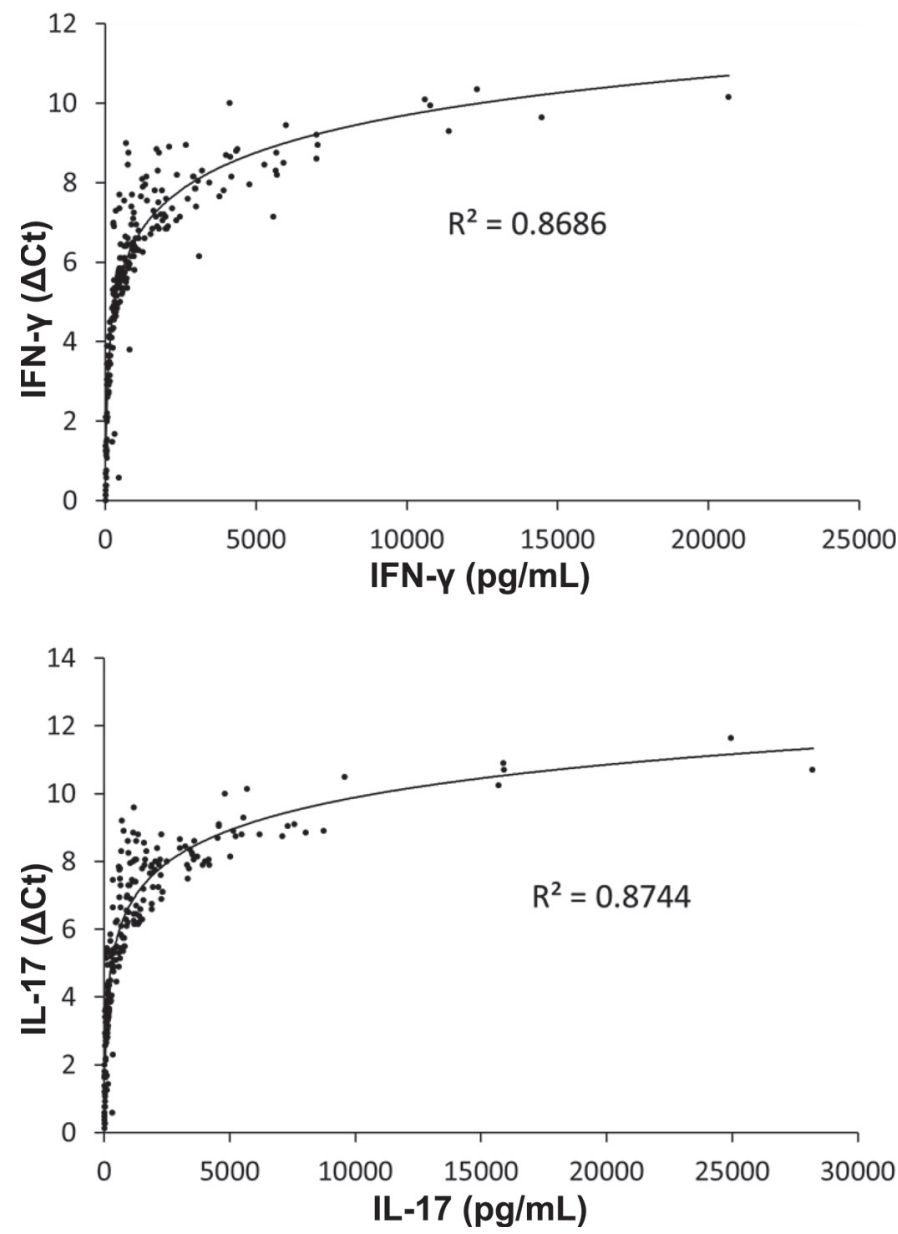

Figure 2. Correlation of cytokine gene expression and cytokine secretion. The graphs represent gene expression, as measured by quantitative real-time PCR, for IFNG (top) and IL17 (bottom) in correlation with cytokine secretion for IFN- $\gamma$ and IL-17 measured by ELISA in the same cultures $(\mathrm{n}=245)$. $\mathrm{Ct}=$ threshold cycle.

were managed differently identified no significant time effects (Heiser et al., 2015) in the expression of these cytokines. The higher baseline expression of these cytokines in the week after calving supports the observation that cows experience a degree of inflammation around parturition (Bertoni et al., 2008; Trevisi et al., 2012) even at a systemic level. Dairy cows going into transition with a BCS5 were less prone to such a systemic inflammatory state.

\section{Cytokine Expression in In Vitro-Stimulated Bovine Blood Leukocytes from Periparturient Cows}

To gain a better understanding of actual leukocyte function, blood cells from dairy cows from all BCS and feeding level groups and from 4 time points were stimulated in vitro with SEB/LPS (as per Heiser et al., 2015), and mRNA expression for IFNG, TNF, IL17, and IL10 was analyzed by qPCR and compared with expression in unstimulated cells. Some samples presented with very low or absent cytokine expression in unstimulated samples, which resulted in high fold-changes when relative expression was calculated. Because the biological relevance of these values is questionable, cytokine RNA expression is presented as $\Delta \Delta \mathrm{Ct}$ (Figure 4).

During the weeks immediately precalving, IFNG was affected by feeding management and time (see Figure 4 ), but we found no effect of precalving BCS. Feeding management affected $I F N G$, with levels higher in B4F125 compared with B4F75 $(P<0.05)$ and B4F100 $(P<0.01)$, as well as B5F125 compared with B5F75 and B5F100 $(P<0.05)$. Expression of $I F N G$ was also affected by time. Compared with Pre, all groups except for B5F125 presented with a significant increase at wk $+1(P<0.01$ for B4F75 and B4F100; $P<0.05$ for $\mathrm{B} 4 \mathrm{~F} 125, \mathrm{~B} 4 \mathrm{~F} 75$, and B5F100). Levels of TNF had less pronounced effects (see Figure 4). An effect of precalving BCS was not detected. Feeding management affected TNF only in the BCS4 group, with levels being higher in B4F125 compared with B4F75 $(P<0.05)$. Time affected $T N F$, with all groups except for B4F75 and B4F125 showing a significant increase at wk +1 $(P<0.05)$. The $I L 17$ expression pattern over time was similar to that of IFNG (see Figure 4), with effects of feeding management and time but not BCS. Levels were higher in B4F125 compared with B4F75 and B4F100 $(P<0.01)$ as well as in B5F125 compared with B5F75 and B5F100 $(P<0.01)$. Expression of $I L 17$ was also affected by time, with all groups increasing at wk $+1(P<0.01)$ relative to the Pre sample and returning to precalving levels in $\mathrm{wk}+2$ and $\mathrm{wk}+4$. We also noted that IL17 expression was lower in B4F75 compared with B4F100 after calving and compared with B4F125 at all times $(P<0.01)$. Levels of IL10 showed similar expression patterns to IFNG but were less prominent. An effect for BCS was detected, with IL10 expression lower in B5F125 than in BCS4F125 $(P<0.01)$. Feeding management also affected $I L 10$, with levels higher in B4F125 $(P<0.01)$ compared with B4F75 and B4F100. Moreover, IL10 was affected by time. All groups, except for B4F125, were higher at wk $+1(P<0.01$ for B4F100, $P<0.05$ for B4F75, all BCS5 groups).

These results allow 2 general observations: (1) cows with high energy intake precalving (125\%) had higher cytokine expression precalving, and (2) all cows had higher cytokine expression in the week after calving. The latter observation confirms what was found in previous studies. A weak association between parturition and higher IFNG production by stimulated cells was reported and linked to a decrease in DNA methylation 

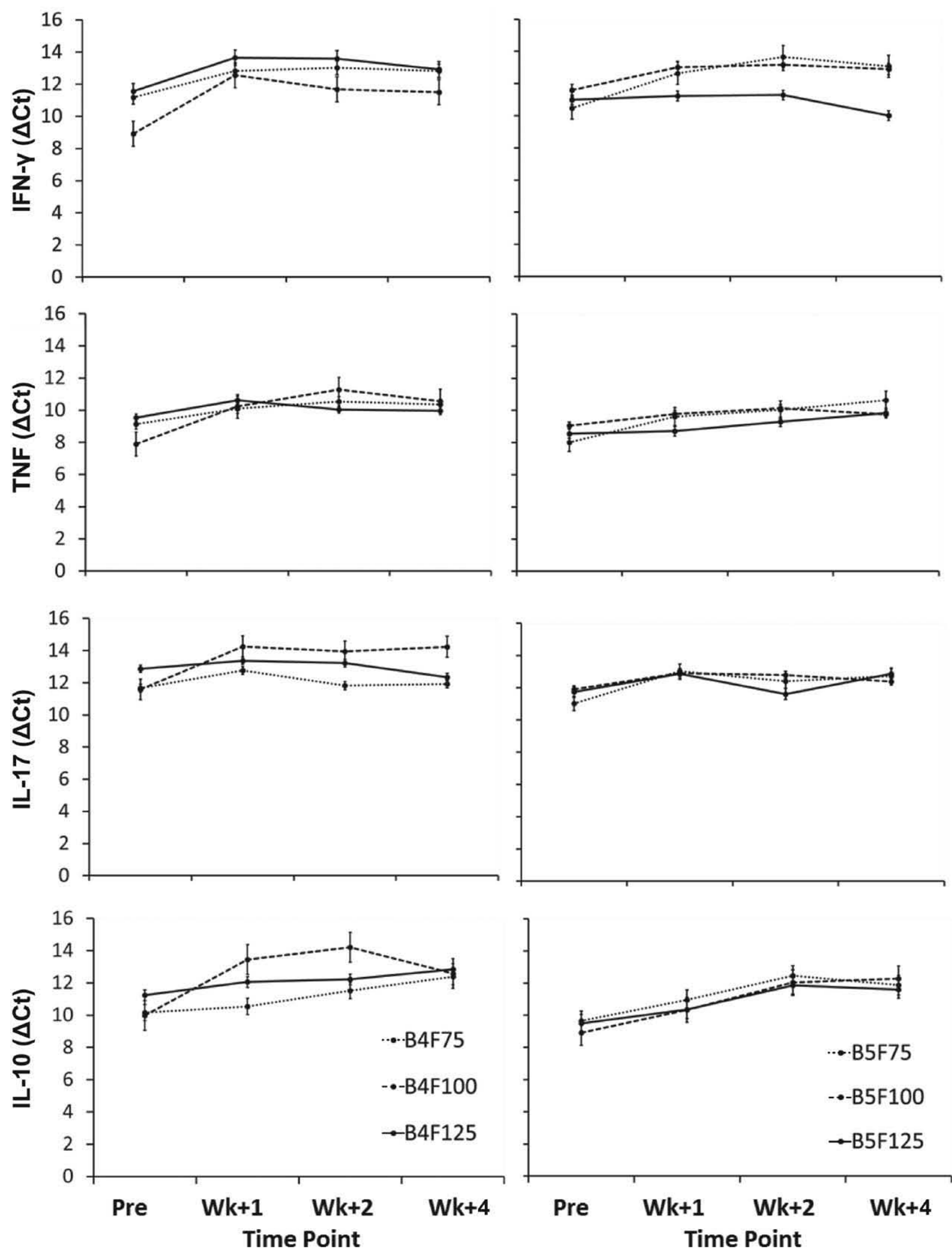

Figure 3. Cytokine expression in bovine blood leukocytes from periparturient cows. The graphs represent gene expression, as measured by quantitative real-time PCR, for IFN- $\gamma$, tumor necrosis factor (TNF), IL-17, and IL-10 in unstimulated blood cells from cows of B4 (BCS = 4.0; left) and B5 (BCS = 5.0; right). Each graph represents results from groups receiving 75, 100, and 125\% of estimated requirements (F75, F100, and F125). Each line represents results from 8 to 13 animals shown as mean $\Delta \mathrm{Ct} \pm \mathrm{SE}$, where $\mathrm{Ct}=$ threshold cycle. 



Figure 4. Cytokine expression in stimulated bovine blood leukocytes from periparturient cows. The graphs represent gene expression as measured by quantitative real-time PCR for IFN- $\gamma$, tumor necrosis factor (TNF), IL-17, and IL-10 in Staphylococcal enterotoxin B/LPS-stimulated blood cells from cows of B4 (BCS = 4.0; left) and B5 (BCS = 5.0; right). Each graph represents results from groups receiving 75,100 , and $125 \%$ of estimated requirements (F75, F100, and F125). Each line represents results from 8 to 13 animals shown as mean $\Delta \Delta \mathrm{Ct} \pm \mathrm{SE}$, where $\mathrm{Ct}=$ threshold cycle. 
of the IFNG promoter region (Paibomesai et al., 2013). An increase in $T N F$ secretion after stimulation of blood leukocytes with concanavalin A has been reported, but only when using autologous serum and not fetal bovine serum (Lessard et al., 2004). Heat stress has also been shown to affect $T N F$ expression during the transition period (Tao et al., 2013). Increased expression of IL10 can be interpreted as an attempt to control the ongoing inflammation (Banchereau et al., 2012). In a previous study using different feeding management, IL10 also was significantly higher $1 \mathrm{wk}$ after calving but IFNG, $T N F$, and $I L 17$ showed the opposite pattern (Heiser et al., 2015), underlining the importance to consider BCS and feeding level precalving. As the baseline expression, the higher stimulated expression of cytokines in the week after calving supports the understanding that transition cows develop a mild systemic inflammation (Bertoni et al., 2008; Trevisi et al., 2012).

Multiple studies have now reported an effect of nutritional state before calving on the level of cytokine expression after calving (Lessard et al., 2004; Lacetera et al., 2005; Paibomesai et al., 2013; Tao et al., 2013; Heiser et al., 2015). In this study, dairy cows going into transition with high energy intake precalving $(125 \%)$ had higher stimulated cytokine expression even precalving, similar to previous findings (Zhou et al., 2015). There is growing evidence that, in other species, overfeeding causes hypertrophic expansion of adipocytes, which contributes to a heightened state of inflammation by recruiting immune cells and induces the release of proinflammatory and inflammatory cytokines, establishing an inflammatory state (Surmi and Hasty, 2008; Manteiga et al., 2013). Our results suggest that similar effects apply in cattle but others did not find a close correlation between energy overfeeding and adipose expression of inflammation-related genes (Ji et al., 2014).

For a better understanding of the underlying factors and the timing of these events, studies are needed with a tighter and more precise monitoring of the period from shortly before until 1 wk after calving.

\section{CONCLUSIONS}

The current study provides evidence that cytokine responses are, indeed, modulated during the week after calving. A recurring observation is that changes in diet and BCS might be the driving forces for immunomodulation in transition cows. Therefore, precalving feeding management becomes particularly important for the maintenance of immunocompetence after calving. Considering the current results, optimally conditioned cows might benefit from a restricted precalving diet, whereas underconditioned cows should be fed to requirements.

\section{ACKNOWLEDGMENTS}

The authors thank Jason Philips, farm manager of Scott Farm (DairyNZ) and his capable team, as well as Stu Morgan, Kate Watkins, Hamish Hodgson, and Chris Roach for technical support, and Barbara Dow and Barbara Kuhn-Sherlock for statistical analysis and advice. This research was supported by New Zealand dairy farmers through DairyNZ Inc. (RD1403; Hamilton, New Zealand), AgResearch Ltd. (Hamilton, New Zealand), and the Ministry of Business, Innovation, and Employment (DRCX1201; Wellington, New Zealand).

\section{REFERENCES}

Akbar, H., T. M. Grala, M. Vailati Riboni, F. C. Cardoso, G. Verkerk, J. McGowan, K. Macdonald, J. Webster, K. Schutz, S. Meier, L. Matthews, J. R. Roche, and J. J. Loor. 2015. Body condition score at calving affects systemic and hepatic transcriptome indicators of inflammation and nutrient metabolism in grazing dairy cows. J. Dairy Sci. 98:1019-1032.

Banchereau, J., V. Pascual, and A. O'Garra. 2012. From IL-2 to IL37: The expanding spectrum of anti-inflammatory cytokines. Nat. Immunol. 13:925-931.

Banos, G., E. Wall, M. P. Coffey, A. Bagnall, S. Gillespie, G. C. Russell, and T. N. McNeilly. 2013. Identification of immune traits correlated with dairy cow health, reproduction and productivity. PLoS ONE 8:e65766.

Bell, A. W. 1995. Regulation of organic nutrient metabolism during transition from late pregnancy to early lactation. J. Anim. Sci. $73: 2804-2819$.

Bensaid, A., and M. Hadam. 1991. Bovine CD4 (BoCD4). Vet. Immunol. Immunopathol. 27:51-54.

Bertoni, G., E. Trevisi, X. Han, and M. Bionaz. 2008. Effects of inflammatory conditions on liver activity in puerperium period and consequences for performance in dairy cows. J. Dairy Sci. 91:3300 3310 .

Boysen, P., and A. K. Storset. 2009. Bovine natural killer cells. Vet. Immunol. Immunopathol. 130:163-177.

Clevers, H., N. D. Machugh, A. Bensaid, S. Dunlap, C. L. Baldwin, A. Kaushal, K. Iams, C. J. Howard, and W. Ivan Morrison. 1990. Identification of a bovine surface antigen uniquely expressed on CD4-CD8 - T cell receptor $\gamma / \delta+\mathrm{T}$ lymphocytes. Eur. J. Immunol. 20:809-817.

Couper, K. N., D. G. Blount, and E. M. Riley. 2008. IL-10: The master regulator of immunity to infection. J. Immunol. 180:5771-5777.

Drackley, J. K., H. M. Dann, G. N. Douglas, N. A. Janovick Guretzky, N. B. Litherland, J. P. Underwood, and J. J. Loor. 2005. Physiological and pathological adaptations in dairy cows that may increase susceptibility to periparturient diseases and disorders. Ital. J. Anim. Sci. 4:323-344.

Gilbert, R. O., Y. T. Gröhn, P. M. Miller, and D. J. Hoffman. 1993. Effect of parity on periparturient neutrophil function in dairy cows. Vet. Immunol. Immunopathol. 36:75-82.

Goff, J. P., and R. L. Horst. 1997. Physiological changes at parturition and their relationship to metabolic disorders. J. Dairy Sci. 80:1260-1268.

Graugnard, D. E., M. Bionaz, E. Trevisi, K. M. Moyes, J. L. SalakJohnson, R. L. Wallace, J. K. Drackley, G. Bertoni, and J. J. Loor. 2012. Blood immunometabolic indices and polymorphonuclear neutrophil function in peripartum dairy cows are altered by level of dietary energy prepartum. J. Dairy Sci. 95:1749-1758.

Hammon, D. S., I. M. Evjen, T. R. Dhiman, J. P. Goff, and J. L. Walters. 2006. Neutrophil function and energy status in Holstein cows with uterine health disorders. Vet. Immunol. Immunopathol. $113: 21-29$. 
Heiser, A., A. McCarthy, N. Wedlock, S. Meier, J. Kay, C. Walker, M. A. Crookenden, M. D. Mitchell, S. Morgan, K. Watkins, J. J. Loor, and J. R. Roche. 2015. Grazing dairy cows had decreased interferon- $\gamma$, tumor necrosis factor, and interleukin-17, and increased expression of interleukin-10 during the first week after calving. J. Dairy Sci. 98:937-946.

Hoek, A., V. P. M. G. Rutten, J. Kool, G. J. A. Arkesteijn, R. J. Bouwstra, I. Van Rhijn, and A. P. Koets. 2009. Subpopulations of bovine WC1+ $\gamma \delta \mathrm{T}$ cells rather than $\mathrm{CD} 4+\mathrm{CD} 25$ highFoxp3+ $\mathrm{T}$ cells act as immune regulatory cells ex vivo. Vet. Res. 40:6.

Ingvartsen, K. L., and K. Moyes. 2013. Nutrition, immune function and health of dairy cattle. Animal 7:112-122.

Ivanov, P., and P. Anderson. 2013. Post-transcriptional regulatory networks in immunity. Immunol. Rev. 253:253-272.

Ji, P., J. K. Drackley, M. J. Khan, and J. J. Loor. 2014. Overfeeding energy upregulates peroxisome proliferator-activated receptor $(\mathrm{PPAR}) \gamma$-controlled adipogenic and lipolytic gene networks but does not affect proinflammatory markers in visceral and subcutaneous adipose depots of Holstein cows. J. Dairy Sci. 97:3431-3440.

Jin, W., and C. Dong. 2013. IL-17 cytokines in immunity and inflammation. Emerg. Microbes Infect. 2:e60.

Karcher, E. L., D. C. Beitz, and J. R. Stabel. 2008. Modulation of cytokine gene expression and secretion during the periparturient period in dairy cows naturally infected with Mycobacterium avium ssp. paratuberculosis. Vet. Immunol. Immunopathol. 123:277-288.

Kehrli, M. E., B. J. Nonnecke, and J. A. Roth. 1989. Alterations in bovine lymphocyte function during the periparturient period. Am. J. Vet. Res. 50:215-220.

Lacetera, N., D. Scalia, U. Bernabucci, B. Ronchi, D. Pirazzi, and A. Nardone. 2005. Lymphocyte functions in overconditioned cows around parturition. J. Dairy Sci. 88:2010-2016.

LeBlanc, S. 2010. Monitoring metabolic health of dairy cattle in the transition period. J. Reprod. Dev. 56(Suppl):S29-S35.

Lessard, M., N. Gagnon, D. L. Godson, and H. V. Petit. 2004. Influence of parturition and diets enriched in $\mathrm{n}-3$ or $\mathrm{n}-6$ polyunsaturated fatty acids on immune response of dairy cows during the transition period. J. Dairy Sci. 87:2197-2210.

Locksley, R. M., N. Killeen, and M. J. Lenardo. 2001. The TNF and TNF receptor superfamilies: Integrating mammalian biology. Cell 104:487-501.

MacHugh, N. D., and P. Sopp. 1991. Individual antigens of cattle. Bovine CD8 (BoCD8). Vet. Immunol. Immunopathol. 27:65-69.

Madsen, S. A., P. S. D. Weber, and J. L. Burton. 2002. Altered expression of cellular genes in neutrophils of periparturient dairy cows. Vet. Immunol. Immunopathol. 86:159-175.

Manteiga, S., K. Choi, A. Jayaraman, and K. Lee. 2013. Systems biology of adipose tissue metabolism: Regulation of growth, signaling and inflammation. Wiley Interdiscip. Rev. Syst. Biol. Med. $5: 425-447$.

Maślanka, T., J. J. Jaroszewski, W. Markiewicz, H. Ziółkowski, and D. Barski. 2012. The presence of CD25 on bovine WC1+ gammadelta $\mathrm{T}$ cells is positively correlated with their production of IL-10 and TGF-beta, but not IFN-gamma. Pol. J. Vet. Sci. 15:11-20.

Naessens, J., M. Sileghem, N. MacHugh, Y. H. Park, W. C. Davis, and P. Toye. 1992. Selection of BoCD25 monoclonal antibodies by screening mouse L cells transfected with the bovine p55-interleukin-2 (IL-2) receptor gene. Immunology 76:305-309.

Nightingale, C. R., M. D. Sellers, and M. A. Ballou. 2015. Elevated plasma haptoglobin concentrations following parturition are asso- ciated with elevated leukocyte responses and decreased subsequent reproductive efficiency in multiparous Holstein dairy cows. Vet. Immunol. Immunopathol. 164:16-23.

Paibomesai, M., B. Hussey, M. Nino-Soto, and B. A. Mallard. 2013. Effects of parturition and dexamethasone on DNA methylation patterns of IFN- $\gamma$ and IL-4 promoters in CD4+ T-lymphocytes of Holstein dairy cows. Can. J. Vet. Res. 77:54-62.

R Core Team. 2015. R: A language and environment for statistical computing. R Foundation for Statistical Computing, Vienna, Austria.

Roche, J. R.. P. G. Dillon, C. R. Stockdale, L. H. Baumgard, and M. J. VanBaale. 2004. Relationships among international body condition scoring systems. J. Dairy Sci. 87:3076-3079.

Roche, J. R., E. S. Kolver, and J. K. Kay. 2005. Influence of precalving feed allowance on periparturient metabolic and hormonal responses and milk production in grazing dairy cows. J. Dairy Sci. 88:677-689.

Roche, J. R., K. A. Macdonald, K. E. Schütz, L. R. Matthews, G. A. Verkerk, S. Meier, J. J. Loor, A. R. Rogers, J. McGowan, S. R. Morgan, S. Taukiri, and J. R. Webster. 2013. Calving body condition score affects indicators of health in grazing dairy cows. J. Dairy Sci. 96:5811-5825.

Roche, J. R., S. Meier, A. Heiser, M. D. Mitchell, C. Walker, M. Crookenden, M. Vailati Riboni, J. J. Loor, and J. Kay. 2015. Effects of precalving body condition score and prepartum feeding level on production, reproduction, and health parameters in pasture-based transition dairy cows. J. Dairy Sci. 98:7164-7182.

Schmitt, E., M. A. Ballou, M. N. Correa, E. J. DePeters, J. K. Drackley, and J. J. Loor. 2011. Dietary lipid during the transition period to manipulate subcutaneous adipose tissue peroxisome proliferator-activated receptor- $\gamma$ co-regulator and target gene expression. J. Dairy Sci. 94:5913-5925.

Schroder, K., P. J. Hertzog, T. Ravasi, and D. A. Hume. 2004. Interferon-gamma: An overview of signals, mechanisms and functions. J. Leukoc. Biol. 75:163-189.

Schwarm, A., T. Viergutz, B. Kuhla, H. M. Hammon, and M. Schweigel-Röntgen. 2013. Fuel feeds function: Energy balance and bovine peripheral blood mononuclear cell activation. Comp. Biochem. Physiol. A Mol. Integr. Physiol. 164:101-110.

Storset, A. K., S. Kulberg, I. Berg, P. Boysen, J. C. Hope, and E. Dissen. 2004. NKp46 defines a subset of bovine leukocytes with natural killer cell characteristics. Eur. J. Immunol. 34:669-676.

Surmi, B. K., and A. H. Hasty. 2008. Macrophage infiltration into adipose tissue. Future Lipidol. 3:545-556.

Tao, S., E. E. Connor, J. W. Bubolz, I. M. Thompson, B. C. do Amaral, M. J. Hayen, and G. E. Dahl. 2013. Short communication: Effect of heat stress during the dry period on gene expression in mammary tissue and peripheral blood mononuclear cells. J. Dairy Sci. 96:378-383.

Trevisi, E., M. Amadori, S. Cogrossi, E. Razzuoli, and G. Bertoni 2012. Metabolic stress and inflammatory response in high-yielding, periparturient dairy cows. Res. Vet. Sci. 93:695-704.

Zhou, Z., D. P. Bu, M. V. Riboni, M. J. Khan, D. E. Graugnard, J. Luo, F. C. Cardoso, and J. J. Loor. 2015. Prepartal dietary energy level affects peripartal bovine blood neutrophil metabolic, antioxidant, and inflammatory gene expression. J. Dairy Sci.98:54925505 . 